\title{
Stimulation of transient versus sustained ERK1/2 phosphorylation by relative chitinase-like proteins CHI3L1 and CHI3L2 correlates with different kinase localization and biological outcome
}

\author{
P. O. Areshkov, S. S. Avdieiev, A. V. Iershov, V. M. Kavsan \\ Institute of Molecular Biology and Genetics, NAS of Ukraine \\ 150, Akademika Zabolotnogo Str., Kyiv, Ukraine, 03680 \\ chitotrio@gmail.com
}

\begin{abstract}
Aim. To determine 293 and U373 cell response and ERK1/2 activation profile after CHI3L1 or CHI3L2 treatment. Methods. Specific activation and localization of ERK1/2 kinases after CHI3L1 or CHI3L2 addition to unsupplemented cell medium were evaluated by Western blots, immunofluorescence and confocal microscopy. To determine whether CHI3L1 or CHI3L2 can enhance mitogenesis, $\left[{ }^{3} H\right]$ thymidine incorporation in cellular DNA was measured. Results. The obtained results show that ERK1/2 phosphorylation was stimulated in both cell types (293 and U373 cells) following addition of CHI3L2 or CHI3L1 in dose- and time-dependent manner. Unexpectedly, in opposite to CHI3L1, the dose-dependent decreasing of measured mitogenesis parameters was observed in 293 and U373 cells. In both cell types the treatment with CHI3L2 gave more sustained than CHI3L1 MAPK-pathway activation with prolonged phospho-ERK1/2 nuclear accumulation in 293 cells. Conclusions. In contrast to the activation of ERK1/2 phosphorylation by CHI3L1 cell treatment, that leads to a proliferative signal, the activation of these kinases by CHI3L2 addition inhibits cell mitogenesis and proliferation in serum starved 293 and U373 cells.
\end{abstract}

Keywords: chitinase 3-like 1 protein (CHI3L1), chitinase 3-like 2 protein (CHI3L2), MAP kinase, mitogenesis.

Introduction. Despite the lack of chitin synthesis in mammalians, their genomes encode a set of homologous chitinase-like proteins (CLPs). In human there are six proteins of this family [1] and CHI3L1 is the most investigated protein of the group. CHI3L2 protein is closely related to CHI3L1 and has significant sequence homology with other mammalian CLPs. CHI3L2 was identified as a protein that co-purified with CHI3L1 from conditioned medium from human articular cartilage chondrocytes primary culture [2]. Overexpression of CHI3L1 and CHI3L2 genes was found in glioblastoma [3-5] and other tumors (reviewed in [6]). It was reported that $\mathrm{CHI} 3 \mathrm{~L} 1$, similarly to IGF1, promotes the

(C) Institute of Molecular Biology and Genetics, NAS of Ukraine, 2011 growth of human fibroblasts by MAPK/ERK1/2 and PI3K/AKT pathways activation [7]. An assumption about CHI3L2 function was gained from the structural similarity with CHI3L1 in size, nucleotide and amino acid sequences, and 3D structure [8]. However, Western blot analysis did not show simultaneous production of CHI3L1 and CHI3L2 in gliomas, apparently indicating their different functions [5].

The work described here demonstrates the possible influence of MAPK signaling duration and the localization of phosphorylated ERK1/2 on the control of mitogenesis and proliferation in CHI3L1 or CHI3L2 treated human glial U373 and embryonic kidney 293 cells.

Materials and methods. 293 cells (Human embryonic kidney 293 cells, also often referred to HEK 
293, or less precisely as HEK cells) and U373 cells (Human glioblastoma-astrocytoma, epithelial-like cells) were kindly provided by Prof. I. Gout (UCL, Cell Signaling and Metabolic Regulation Dept., UK). Cells were grown in DMEM supplemented with $10 \%$ FBS and $100 \mu \mathrm{g} / \mathrm{ml}$ penicillin, 100 units $/ \mathrm{ml}$ streptomycin in an environment of $5 \% \mathrm{CO}_{2}$.

Native CHI3L1 was purified from conditioned MG63 cell medium as described by Harvey et al. [9]. Synthesis of recombinant CHI3L2 was performed according to our previous description [5]. Antibodies were obtained from multiple sources and used at the specified dilutions for immunofluorescence microscopy: $\mathrm{p} 44 /$ 42 MAP (ERK1/2) (L34F12) Mouse mAb («Cell Signaling Technology», USA) 1:100 (anti-phospho-ERK); ERK2 (K-23) Rabbit polyclonal IgG («Santa Cruz Biotechnology», USA) 1:100 (pan-anti-ERK1/2); Fluorescein Anti-Mouse $\operatorname{IgG}(\mathrm{H}+\mathrm{L})$ as well as Texas $\operatorname{Red}^{\mathbb{}}$ Anti-Rabbit IgG («Vector Laboratories Inc.», USA) 1:400; and for immunoblots: pERK (E-4) Mouse monoclonal IgG («Santa Cruz», USA) 1:2000 (antiphospho-ERK1/2); ERK2 (K-23) Rabbit polyclonal IgG 1:3000 (pan-anti-ERK1/2); Anti-Mouse IgG ( $\mathrm{H}+$ L), HRP Conjugate and Anti-Rabbit IgG (H+L), HRP Conjugate («Promega», USA) 1:20000 (HRP-antimouse IgG), (HRP-anti-rabbit IgG).

The reagents for enhanced chemiluminescence (ECL) from «Sigma-Aldrich Co.» (USA) and «Fluka» (Switzerland) were used for the visualization of immunoreactive bands on Western blots.

Mitogenic activity was assessed by determination of DNA-synthesis rates of treated and untreated cell cultures. 293 cells or U373 cells were seeded into 24-well tissue-culture plates and allowed growing to near-confluence in DMEM supplemented with $10 \% \mathrm{FBS}$, followed by a $24 \mathrm{~h}$ serum-starvation period in unsupplemented DMEM, CHI3L1 and CHI3L2 were added at the concentration of $100 \mathrm{ng} / \mathrm{ml}$, followed by $\left[{ }^{3} \mathrm{H}\right]$ thymidine $(3 \mu \mathrm{Ci} / \mathrm{ml})$ («Amersham», UK) $2 \mathrm{~h}$ later. Cultivation was stopped after $24 \mathrm{~h}$ of exposure and the cell layers were briefly washed twice by PBS and lysed in $0.5 \mathrm{M} \mathrm{NaOH}$ with $0.5 \%$ SDS. DNA was collected on glass-fibre filters («Whatman», UK) and washed with $5 \%$ trichloroacetic acid. $\left[{ }^{3} \mathrm{H}\right]$ thymidine content was determined by liquid scintillation spectroscopy using a Perkin Elmer scintillation counter.

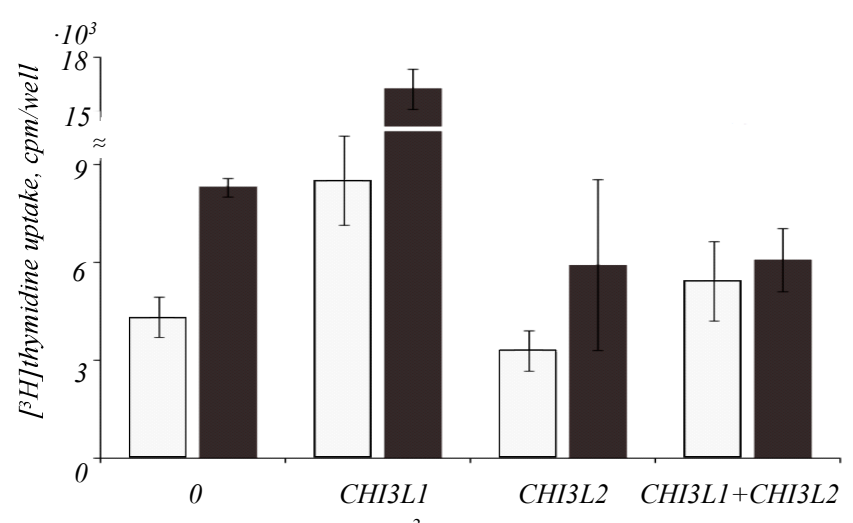

Fig. 1. Cell mitogenesis assay. $\left[{ }^{3} \mathrm{H}\right]$ thymidine incorporation in cells (white column - U273; black - 293) treated with CHI3L1 or CHI3L2

Investigation of ERK $1 / 2$ phosphorylation was performed according to our previous description [10]. Briefly, cells were seeded into 6-well tissue culture plates in DMEM contained $10 \% \mathrm{FBS}$ and allowed to grow to near-confluence, serum-starved for $24 \mathrm{~h}$, followed by exposure to $\mathrm{CHI} 3 \mathrm{~L} 1$ or $\mathrm{CHI} 3 \mathrm{~L} 2$ for time periods up to $2 \mathrm{~h}$. At the end of the incubation periods, cell layers were washed twice in ice-cold PBS and whole cell lysates were mixed with $2 \times$ Laemmli sample buffer, boiled, proteins resolved by SDS-PAGE and transferred to nitrocellulose membrane. Membranes were blocked with $5 \%$ powdered skim milk, reacted with anti-phospho-ERK, and then incubated with HRP-anti-mouse. Blots were developed with an ECL detection system. Membranes were treated in stripping buffer and incubated with pan-anti-ERK. After incubation with HRPanti-rbbit IgG for $1 \mathrm{~h}$, total ERK $1 / 2$ was detected with ECL. Specific activation of MAP kinases was measured by densitometric analysis of Western blot signals using Scion Image 1.62c program (NIH ImageJ; NIH, Bethesda, MD).

For immunofluorescence and confocal microscopy, cells were seeded on coverslips and allowed to grow to near-confluence. Cells were then serum-starved for $24 \mathrm{~h}$, followed by exposure to CHI3L1 or CHI3L2 $(100 \mathrm{ng} / \mathrm{ml})$ for time periods up to $4 \mathrm{~h}$. After treatment, immunofluorescence analysis was performed as described by Volmat et al. [11].

Results and discussion. A dose-dependent decrease of mitogenesis was observed in the cells of tumor (U373) and non-tumor (293) origin treated with CHI3L2 (Fig. 1). The simultaneous addition of both CHI3L1 and CHI3L2 chitinase-like proteins showed the inhibition of $\left[{ }^{3} \mathrm{H}\right]$ thymidine incorporation in DNA of both cell types 
Figures to article by P. O. Areshkov et al.

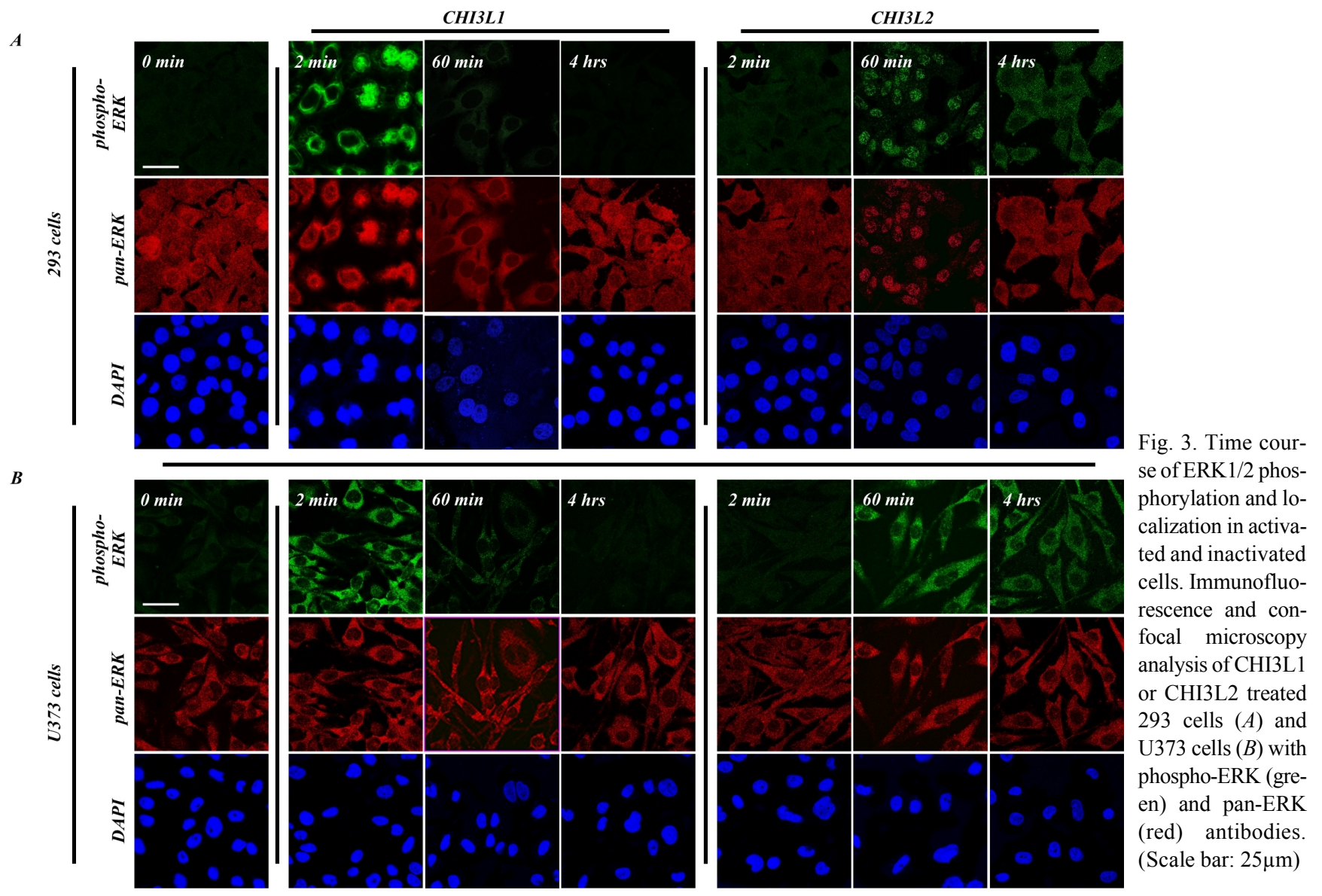

Figure to article by L. Kobbi et al.

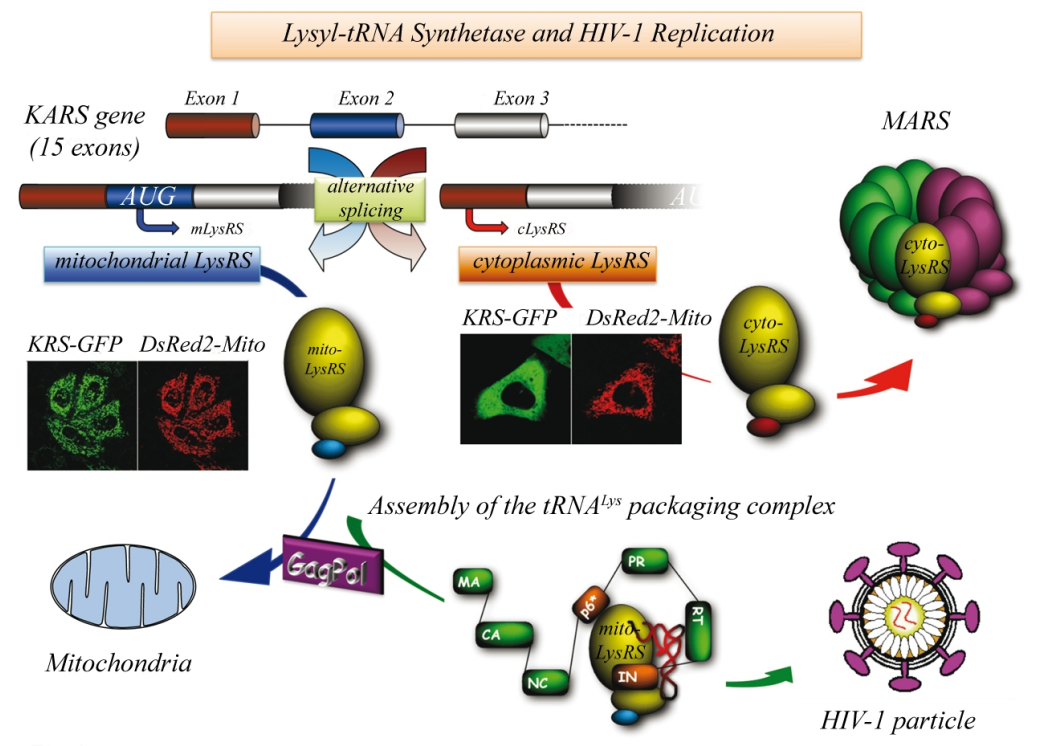

In human, a single gene encodes the cytoplasmic and mitochondrial forms of lysyl-tRNA synthetase by means of alternative splicing. The cytoplasmic isoform is produced from the mRNA lacking exon 2. This isoform is targeted to the MARS (Multi Aminoacyl-tRNA Synthetase) complex. The mitochondrial species is produced by translation initiation at the level of exon 2. Mitochondrial LysRS is specifically hijacked by the GagPol precursor protein during the process of packaging of HIV-1 particles. Association of mLysRS with GagPol involves catalytic domain of the synthetase and transframe (p6*) and integrase domains of the Pol region of GagPol. The formation of the tRNA(Lys, 3) packaging complex is an essential process of the HIV-1 life cycle, since this tRNA is required for initiation of reverse transcription of the RNA genome of HIV-1. The tRNA(Lys, 3) packaging complex is a potential therapeutic target 

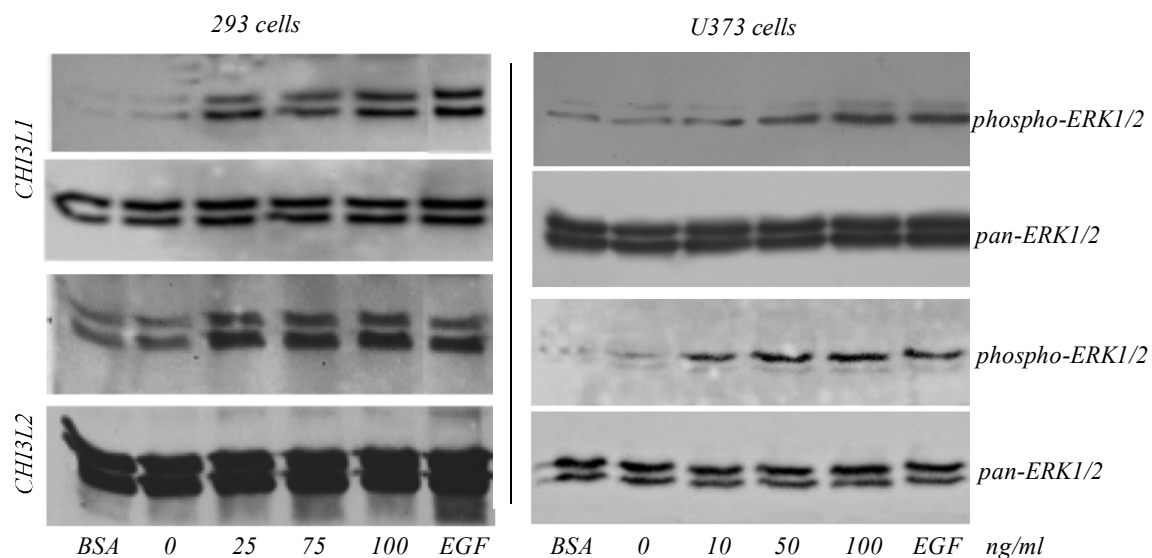

Fig. 2. Dose-dependent induction of ERK1/2 phosphorylation. Western blot analysis of total lysates of CHI3L1 or CHI3L2 treated cells (BSA - $100 \mathrm{ng} / \mathrm{ml}$; EGF - $50 \mathrm{ng} / \mathrm{ml}$ ) indicating that proliferative influence of CHI3L1 was inhibited with CHI3L2 addition. The obtained results demonstrate that CHI3L1 and CHI3L2 possess antagonistic properties in spite of their quite similar structure.

Using Western blot analysis we showed, that similarly to CHI3L1, the treatment of both U373 and 293 cell lines with CHI3L2 leads to phosphorylation of ERK1/2 (Fig. 2). However, CHI3L2 and CHI3L1 mediated phosphorylation of ERK $1 / 2$ occurred in the timeand place-dependent manner. In 293 and U373 cells, the CHI3L1 mediated phosphorylation of ERK1/2 is transient. Even after 2 min of the treatment with CHI3L1 cells became brightly fluorescent, while in $60 \mathrm{~min}$ we did not see any phosphorylation of ERK1/2. At the same time the treatment of cells with CHI3L2 leads to prolong ERK1/2 phosphorylation, which was maintained for more than $4 \mathrm{~h}$. Moreover, such event was entailed by translocation of phosphorylated ERK $1 / 2$ to the cell nucleus (Fig. 3, see inset). Previously, using the model of cells PC-12 treated with NGF, it was shown that translocated to the nucleus ERK1/2 could activate several transcription factors leading to the inhibition of proliferation and apoptosis or to differentiation of cells [12].

Acknowlegements. The work was supported by grants N Ф40.4/018 «Пошук і характеристика онкогенів і пухлинних генів-супресорів, що приймають участь в ініціації та розвитку гліом» спільної україно-російської програми фундаментальних досліджень «ДФФД-РФФД-011» and «Створення системи інгібування росту пухлин головного мозку на основі нанокон'югатів антисенс-олігонуклеотидів та антитіл, специфічних до онкобілків, з природними біополімерами» Державної цільової науково-технічної програми «Нанотехнології та наноматеріали».
П. О. Арешков, С. С. Авдєєв, А. В. Сриов, В. М. Кавсан

Стимуляція короткотривалого $v s$ довготривалого фосфорилювання кіназ ERK1/2 додаванням двох близькоспоріднених білків CHI3L1 і CHI3L2 корелює зі зміною локалізації відповідних кіназ та біологічною відповіддю активованих клітин

Резюме

Мета. Визначити клітинну відповідь та встановити профіль активації кіназ ERK1/2 після обробки клітин 293 та U373 білками CHI3L1 чи CHI3L2. Методи. Специфічну активачію і локалізаиію кіназ ERK1/2 після внесення білків CHI3L1 або CHI3L2 до клітинного середовища, що не містить сироватки, проаналізовано Вестерн-блот аналізо та методами імунофлуоресцениії $і$ конфокальної мікроскопії. Для встановлення, чи зможе додавання білків CHI3L1 або CHI3L2 посилювати мітогенез, застосовано аналіз інкорпораиії [ $\left.{ }^{3} H\right]$ тимідину в клітинну ДНК. Результати. Отримані результати демонструють, що стимуляція фосфорилювання кіназ ERK1/2 після додавання CHI3L1 або CHI3L2 має дозо- та часозалежний характер. Виявилося, що, на відміну від CHI3L1, дозозалежне пригнічення інкорпораиії [ ${ }^{3}$ H]тимідину констатовано у 293 та U373 клітинах. В обох типах клітин обробка білком CHI3L2 викликає тривалішу активаиію каскаду МАРК, ніж обробка білком CHI3L1, з акумулюванням кіназ ERK1/2 у ядрі клітин 293. Висновки. На противагу активачії фосфорилювання кіназ ERK1/2 внаслідок обробки клітин білком CHI3L1, що спричиняе проліферацію, стимуляція ичих кіназ додаванням білка CHI3L2 пригнічує мітогенез у клітинах 293 та U373, щео перебувають у стані сироваткового голодування.

Ключові слова: хітиназа 3-подібний білок 1 (CHI3L1), хітиназа 3-подібний білок 2 (CHI3L2), МАР-кіназа, мітогенез.

\section{П. А. Арешков, С. С. Авдеев, А. В. Ершов, В. М. Кавсан}

Стимуляция кратковременного vs длительного фосфорилирования киназ ERK1/2 добавлением двух близкородственных белков CHI3L1 и CHI3L2 коррелирует c изменением локализации соответствующих киназ и биологическим ответом активированных клеток

Резюме

Цель. Определить клеточный ответ и профиль активации киназ ERK1/2 после обработки клеток 293 и U373 белками CHI3L1 или CHI3L2. Mетоды. Специфическую активаџию и локализаџию киназ ERK1/2 после внесения белков CHI3L1 или CHI3L2 в клеточ- 
ную среду, где отсутствует сыворотка, проанализировано методами Вестерн-блот анализа, иммунофлуоресценции и конфокальной микроскопии. Для определения, будет ли добавление белков CHI3L1 или CHI3L2 увеличивать митогенез, использован анализ инкорпорачии [3] Н]тимидина в клеточную ДНК. Результаты. Полученные результаты демонстрируют, что стимуляиия фосфорилирования киназ ERK1/2 после добавления CHI3L1 либо CHI3L2 имеет зависящий от дозы и времени характер. Оказалось, что, в отличие от CHI3L1, дозозависимое угнетение инкорпорации [3 H] тимидина констатировано в 293- и U373-клетках. В обоих типах клеток обработка белком CHI3L2 вызывает более длительную активацию каскада МАPК, нежели обработка белком CHI3L1, с аккумуляцией киназ ERK1/2 в ядрах клеток 293. Выводы. В отличие от активачии фосфорилирования киназ ERK1/2 после обработки клеток белком CHI3L1, приводящей к пролифераџии, стимуляичия этих киназ добавлением белка CHI3L2 угнетает митогенез в клетках 293 и U373, находящихся в состоянии сывороточного голодания.

Ключевые слова: хитиназа 3-подобный белок 1 (СНI3L1), хитиназа 3-подобный белок 2 (СНI3L2), МАР-киназа, митогенез.

\section{REFERENCES}

1. Bussink A. P., Speijer D., Aerts J. M., Boot R. G. Evolution of mammalian chitinase(-like) members of family 18 glycosyl hydrolases // Genetics.-2007.-177, N 2.-P. 959-970

2. Hu B., Trinh K., Figueira W. F., Price P. A. Isolation and sequence of a novel human chondrocyte protein related to mammalian members of the chitinase protein family // J. Biol. Chem.1996.-271, N 32.-P. 19415-19420.

3. Garifulin O. M., Shostak K. O., Dmitrenko V. V., Rozumenko V. D., Khomenko O. V., Zozulya Yu. A., Zehetner G., Kavsan V. M. The genes SOX-2 and HC gp-39 are overexpressed in astrocytic gliomas // Biopolym. Cell.-2002.-18, N 4.-P. 324-329.

4. Shostak K., Labunskyy V., Dmitrenko V., Malisheva T., Shamayev M., Rozumenko V., Zozulya Y., Zehetner G., Kavsan V. HC gp-39 gene is upregulated in glioblastomas // Cancer Lett.2003.-198, N 2.-P. 203-210.

5. Kavsan V., Dmitrenko V., Boyko O., Filonenko V., Avdeev S., Areshkov P., Marusyk A., Malysheva T., Rozumenko V., Zozulya $Y$. Overexpression of YKL-39 gene in glial brain tumors // Scholarly Research Exchange.-2008.-doi: 10.3814/2008/814849.

6. Johansen J. S. Studies on serum YKL-40 as a biomarker in diseases with inflammation, tissue remodelling, fibroses and cancer // Dan. Med. Bull.-2006.-53, N 2.-P. 172-209.

7. Recklies A. D., White C., Ling H. The chitinase 3-like protein human cartilage glycoprotein 39 (HC-gp39) stimulates proliferation of human connective-tissue cells and activates both extracellular signal-regulated kinase- and protein kinase B-mediated signalling pathways // Biochem J.-2002.-365, Pt 1.-P. 119-126.

8. Iershov A., Odynets K., Kornelyuk A., Kavsan V. Homology modeling of 3D structure of human chitinase-like protein CHI3L2 // Central Eur. J. Biol.-2010.-5, N 4.-P. 407-420.

9. Harvey S., Weisman M., O'Dell J., Scott T., Krusemeier M., Visor J., Swindlehurst $C$. Chondrex: new marker of joint disease // Clin Chem.-1998.-44, N 3.-P. 509-516.

10. Areshkov P. O., Kavsan V. M. The chitinase 3-like human protein 2 (CHI3L2) activates ERK1/2 signaling pathway in human embryonic kidney cells (HEK293) // Biopolym. Cell.-2009.25, N 6.-P. 500-503.

11. Volmat V., Camps M., Arkinstall S., Pouyssegur J., Lenormand $P$. The nucleus, a site for signal termination by sequestration and inactivation of p42/p44 MAP kinases // J. Cell Sci.-2001.-114, Pt 19.-P. 3433-3443.

12. Traverse S., Gomez N., Paterson H., Marshall C., Cohen P. Sustained activation of the mitogen-activated protein (MAP) kinase cascade may be required for differentiation of PC12 cells. Comparison of the effects of nerve growth factor and epidermal growth factor // Biochem. J.-1992.-288, Pt 2.P. 351-355.
UDC 577.22

Received 10.06.11 